\title{
PENGARUH PENAMBAHAN FIBER (SERAT POLYPROPYLENE) TERHADAP KUAT GESER TANAH GAMPONG MANE KRUENG
}

\author{
Adzuha Desmi \\ Jurusan Teknik Sipil Universitas Malikussaleh \\ Email :adz.3131@gmail.com
}

\begin{abstract}
Abstrak
Berdasarkan ukuran butiran tanah diklasifikasikan atas empat kelas yaitu kerikil (gravel), pasir (sand), lanau (silt), dan lempung (clay). Sifat yang khas dari tanah lempung adalah dalam keadaan kering dia akan bersifat keras, dan jika basah akan bersifat lunak plastis dan kohesif, mengembang dan menyusut dengan cepat, sehingga mempunyai perubahan volume yang besar karena pengaruh air. Kekuatan geser tanah merupakan kemampuan tanah melawan tegangan geser yang terjadi pada saat terbebani. Penelitian ini bertujuan untuk mengetahui karakteristik tanah lempung sesudah penambahan fiber (serat polypropylene) terhadap nilai kuat geser tanah. Hasil yang didapat dari pengujian Laboratorium Mekanika Tanah Teknik Sipil Universitas Malikussaleh untuk tanah asli $\mathrm{c}=6,402 \mathrm{~kg} / \mathrm{cm}^{2}, 3 \%$ polypropylene $\mathrm{c}=6,963 \mathrm{~kg} / \mathrm{cm}^{2}, 5 \%$ polypropylene $\mathrm{c}=, 370 \mathrm{~kg} / \mathrm{cm}^{2}, 7 \%$ polypropylene $\mathrm{c}=8,609 \mathrm{~kg} / \mathrm{cm}^{2}$. Semakin ada penambahan serat polypropylene maka semakin besar pengaruh nilai parameter kuat geser tanah di karenakan daya tarik permukaan partikel antara tanah dan fiber semakin besar serta akibat karakteristik fiber tersebut. Pengaruh hasil sudut geser yang bervariasi dikarenakan penambahan serat yang ditidak seragam atau tidak sama.
\end{abstract}

Kata kunci: tanah lempung, serat polypropylene, kuat geser tanah

\section{Pendahuluan}

Tanah merupakan material yang terdiri dari agregat (butiran) mineral padat yang tidak tersementasi (terikat secara kimia) satu sama lain dan dari bahan-bahan organik yang telah melapuk (yang berpartikel padat) disertai dengan zat cair dan gas yang mengisi ruang-ruang kosong di antara partikel-partikel padat tersebut (Braja M. Das, 1995). Tanah berguna sebagai bahan bangunan pada berbagai macam pekerjaan teknik sipil, disamping itu tanah berfungsi juga sebagai pendukung pondasi dari bangunan. Tanah lempung merupakan agregat partikelpartikel berukuran mikroskopik dan submikroskopik yang berasal dari pembusukan kimiawi unsur-unsur penyusun batuan, dan bersifat plastis dalam selang kadar air sedang sampai luas. Pada kadar air yang lebih tinggi (basah) lempung bersifat lengket. Kekuatan geser tanah merupakan kemampuan tanah melawan tegangan geser yang terjadi pada saat terbebani. Faktor yang mempengaruhi kuat geser tanah (pengaruh lapangan) adalah keadaan tanah, jenis tanah, kadar air (terutama lempung), jenis beban dan tingkatnya. Keruntuhan geser tanah terjadi bukan disebabkan karena hancurnya butir-butir tanah tersebut tetapi karena andanya gerak relative antara butir-butir tanah tersebut.

Sifat-sifat tanah yang buruk dan kurang menguntungkan bila digunakan sebagai dasar suatu bangunan atau kontruksi, antara lain plastisitas yang tinggi, kekuatan geser yang rendah, kemampatan atau perubahan volume yang besar dan potensi kembang susut yang besar. Berbagai cara digunakan untuk memperbaiki 
kekuatan dari tanah lempung, di antaranya dengan penambahan bahan kimia (stabilisasi secara kimiawi). Guna mengatasi permasalahan yang ada pada tanah lempung maka diadakan penelitian dengan menggunakan fiber (serat polypropylene) sebagai bahan stabilisasinya untuk memperbaiki pengaruh kuat geser tanah.

\section{Tinjauan Kepustakaan}

\subsection{Tanah}

Menurut Braja M. Das (1995), tanah umumnya dapat disebut sebagai kerikil (gravel), pasir (sand), lanau (slit), atau lempung (clay), tergantung pada ukuran partikel yang paling dominan pada tanah tersebut. Untuk menerangkan tentang tanah berdasarkan ukuran-ukuran partikel tanah, beberapa organisasi telah mengembangkan batasan-batasan ukuran golongan jenis tanah, diperlihatkan pada Tabel 1.

Tabel 1 Batasan-Batasan Ukuran Golongan Tanah

\begin{tabular}{|l|c|c|c|c|}
\hline \multicolumn{1}{|c|}{ Nama golongan } & \multicolumn{4}{c|}{ Ukuran butiran (mm) } \\
\cline { 2 - 5 } & Kerikil & Pasir & Lanau & Lempung \\
\hline $\begin{array}{l}\text { Massachusetts Institute of Technology } \\
\text { (MIT) }\end{array}$ & $>2$ & $2-0,06$ & $0,06-0,002$ & $<0,002$ \\
\hline U.S. Departemen of Agriculture (USDA) & $>2$ & $2-0,05$ & $0,05-0,002$ & $<0,002$ \\
\hline $\begin{array}{l}\text { America Association of State Highway } \\
\text { and Transportation Offical (AASHTO) }\end{array}$ & $76,2-2$ & $2-0,075$ & $0,075-0,002$ & $<0,002$ \\
\hline $\begin{array}{l}\text { Unified Soil Classification System (U.S. } \\
\text { Army Corps of Engineer, U.S. Bureau of } \\
\text { Reclamation) }\end{array}$ & $76,2-4,75$ & $4,75-0,075$ & $\begin{array}{c}\text { Halus (yaitu lanau dan } \\
\text { lempung) }<0,0075\end{array}$ \\
\hline
\end{tabular}

Sumber: Braja M. Das (1995)

\subsection{Sistem Klasifikasi Tanah (AASHTO)}

Menurut Braja M. Das, 1995, sistem ini dikembangkan pada tahun 1929 sebagai Public Road Administrator System. Pada sistem ini, tanah diklasifikasikan ke dalam tujuh kelompok besar, yaitu A-1 sampai dengan A-7.

\section{Tabel 2 Sistem Klasifikasi (AASHTO)}

\begin{tabular}{|c|c|c|c|c|c|c|c|c|c|c|c|}
\hline \multirow{3}{*}{$\begin{array}{l}\text { Klasifikasi umum } \\
\text { Klasifikasi kelompok }\end{array}$} & \multicolumn{7}{|c|}{$\begin{array}{c}\text { Tanah berbutir } \\
\text { (35\% atau kurang dari seluruh contoh tanah lolos ayakan } \\
\text { No.200) }\end{array}$} & \multicolumn{4}{|c|}{$\begin{array}{l}\text { Tanah lanau-lempung (lebih dari } \\
35 \% \text { dariseluruh contoh tanah } \\
\text { lolos ayakan No. 200) }\end{array}$} \\
\hline & \multicolumn{2}{|c|}{$\mathrm{A}-1$} & \multirow{2}{*}{ A-3 } & & \multicolumn{3}{|c|}{ A-7 } & \multirow{2}{*}{ A-4 } & \multirow{2}{*}{ A-5 } & \multirow{2}{*}{ A-6 } & \multirow{2}{*}{$\begin{array}{l}\text { A-7 } \\
\text { A-7-5* } \\
\text { A- }-7-6 *\end{array}$} \\
\hline & A-1-a & A-1-b & & A-2-4 & A-2-5 & A-2-6 & A-2-7 & & & & \\
\hline $\begin{array}{l}\text { Analisa ayakan }(\% \\
\text { lolos) } \\
\text { No. } 10 \\
\text { No. } 40 \\
\text { No. } 200\end{array}$ & $\begin{array}{l}\text { Maks } 50 \\
\text { Maks } 15\end{array}$ & $\begin{array}{l}\text { Maks } 50 \\
\text { Maks } 25\end{array}$ & Maks 51 & Maks 35 & Maks 35 & Maks 35 & Maks 35 & Maks 35 & Maks 35 & Maks 35 & Maks 35 \\
\hline $\begin{array}{l}\text { Sifat fraksi yang lolos } \\
\text { ayakan No. } 40 \\
\text { Batas cair (LL) } \\
\text { Indeks plastisitas (PI) }\end{array}$ & \multicolumn{2}{|c|}{ Maks 6} & NP & $\begin{array}{l}\text { Maks 40 } \\
\text { Maks 10 }\end{array}$ & $\begin{array}{l}\text { Maks } 41 \\
\text { Maks } 10\end{array}$ & $\begin{array}{l}\text { Maks 40 } \\
\text { Maks 11 }\end{array}$ & \begin{tabular}{|l|} 
Maks 41 \\
Maks 11
\end{tabular} & $\begin{array}{l}\text { Maks } 40 \\
\text { Maks } 10\end{array}$ & $\begin{array}{l}\text { Maks } 41 \\
\text { Maks 10 }\end{array}$ & $\begin{array}{l}\text { Maks } 40 \\
\text { Maks 11 }\end{array}$ & $\begin{array}{l}\text { Maks 41 } \\
\text { Maks 11 }\end{array}$ \\
\hline $\begin{array}{l}\text { Tipe material yang } \\
\text { paling dominan }\end{array}$ & \multicolumn{2}{|c|}{$\begin{array}{l}\text { Batu pecah, } \\
\text { kerikil dan } \\
\text { pasir }\end{array}$} & $\begin{array}{l}\text { Pasir } \\
\text { halus }\end{array}$ & \multicolumn{4}{|c|}{$\begin{array}{l}\text { Kerikil dan pasir yang } \\
\text { berlanau atau berlumpung }\end{array}$} & \multicolumn{2}{|c|}{$\begin{array}{c}\text { Tanah } \\
\text { berlanau }\end{array}$} & \multicolumn{2}{|c|}{$\begin{array}{c}\text { Tanah } \\
\text { berlempung }\end{array}$} \\
\hline $\begin{array}{l}\text { Penilaian sebagai } \\
\text { bahan tanah dasar }\end{array}$ & \multicolumn{7}{|c|}{ Baik sekali sampai baik } & \multicolumn{4}{|c|}{ Bisa sampai jelek } \\
\hline
\end{tabular}

Sumber: Braja M. Das (1995) 
Tanah yang diklasifikasikan ke dalam A-1, A-2, dan A-3 adalah tanah berbutir dimana $35 \%$ atau kurang dari jumlah butiran tanah tersebut lolos ayakan No. 200. Tanah yang lebih dari $35 \%$ butiran lolos ayakan No.200 diklasifikasikan ke dalam kelompok A-4, A-5, A-6, dan A-7. Butiran dalam kelompok A-4 sampai dengan A-7 tersebut sebagian besar adalah lanau dan lempung. Sistem klasifikasi AASHTO yang dipakai diperlihatkan pada Tabel 2

\subsection{Tanah Lempung}

Menurut Bowles (1993) pada umumnya apabila lebih dari 50 persen dari deposit mengandung partikel-partikel berukuran 0,002 $\mathrm{mm}$ dan lebih kecil, deposit tersebut disebut "lempung". Jarang terdapat deposit lempung murni secara alamiah, lempung selalu terkontaminasi dengan lanau atau partikel-partikel pasir halus atau juga oleh koloid (<0,001). Menurut Braja M. Das (1995) lempung didefinisikan sebagai golongan partikel yang berukuran kurang dari 0,002. Belum tentu tanah dengan ukuran pertikel lempung tersebut juga mengandung mineral tertentu yang "menghasilkan sifat-sifat plastis pada tanah yang dicampur dengan air (Grim, 1953). Jadi dari segi mineral, tanah juga dapat disebut sebagai tanah bukan lempung (non-clay soils) meskipun terdiri dari partikel-partikel yang sangat kecil (partikel-partikel quartz, feldspar, dan mika dapat berukuran submikroskopis, tetapi umumnya mereka tidak dapat menyebabkan terjadinya sifat plastis dari tanah). Dari segi ukuran, partikel-partikel tersebut memang dapat digolongkan sebagai partikel lempung.

\subsection{Pemadatan Tanah}

Pada dasarnya pemadatan tanah merupakan usaha untuk mempertinggi kepadatan tanah dengan pemakain energi mekanis untuk menghasilkan pemampatan partikel. Tanah dapat dikerjakan pada mulanya dengan pengeringan, penambahan air, agregat (butir-butir) tersebut dengan bahan-bahan stabilisasi seperti semen Portland (PC), gamping, abu batu bara atau bahan lainnya.

Apabila diketahui tanah basah di dalam cetakan yang volumenya diketahui, maka berat isi basah dapat langsung dihitung dengan persamaan 1 di bawah ini :

$$
\text { zbasah }=\frac{\text { Berat tanah basah di dalam cetakan }}{\text { Volume cetakan }}
$$

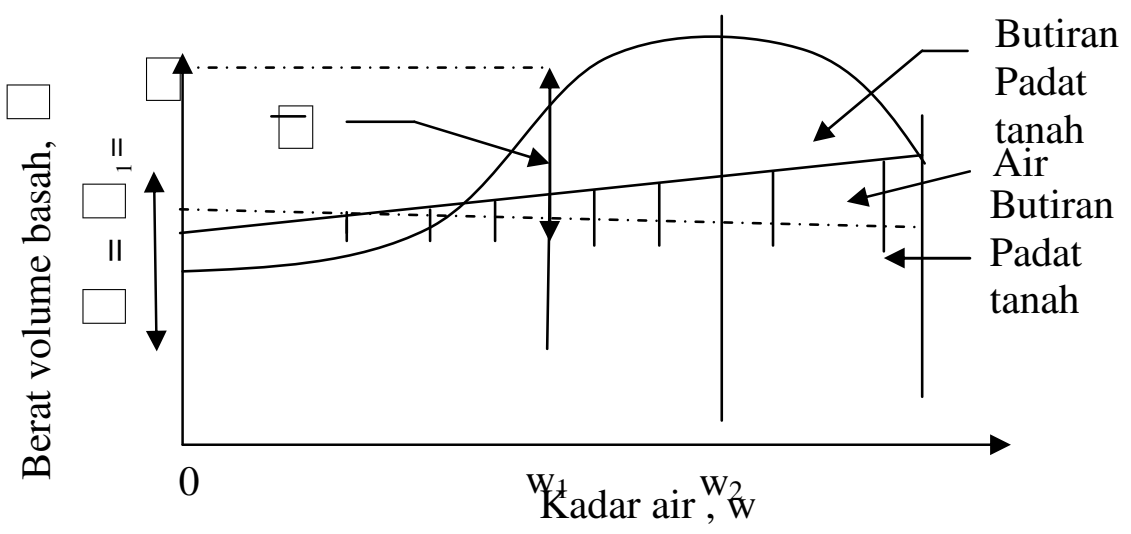

Gambar 1 Prinsip pemadatan

Sumber : Braja M. Das (1995)

Pengaruh Penambahan Serta Fiber (Serat Polypropylene) Terhadap Kuat Geser 
Dari uji pemadatan dapat diketahui derajat kepadatan tanah yang diukur dari berat volume keringnya. Hubungan berat volume kering $(\gamma \mathrm{d})$ dengan berat volume basah $(\gamma b)$ dan kadar air $(w)$ dinyatakan dengan persamaan 2 :

$$
\gamma=\frac{\not b}{1+w}
$$

Dimana $\gamma \mathrm{b}$ adalah berat volume tanah basah $(\mathrm{gr} / \mathrm{cm} 3), \gamma d$ adalah berat volume tanah kering (gr/cm3), dan w adalah kadar air (\%).

Setelah dilakukan pemadatan kerapatan butiran dan kadar air tanah juga kerapatan keringnya ditentukan. Proses ini diulangi sedikitnya lima kali untuk tanah yang sama, dan kadar air contoh tanah tersebut dinaikkan pada setiap proses. Untuk suatu kadar air tertentu, berat volume kering maksimum secara teoritis didapat bila pori-pori tanah sudah tidak ada udara lagi, yaitu pada saat di mana derajad kejenuhan tanah sama dengan 100\%. Jadi, berat volume kering maksimum (teoritis) pada suatu kadar air tertentu dengan kondisi "zero air voids" (pori-pori tanah tidak mengandung udara sama sekali) dapat di tulis sebagai :

$$
\gamma a v=\frac{G s \gamma \omega}{1+e}
$$

Dimana $\gamma_{\text {zav }}$ adalah berat volume pada kondisi zero air void, $\gamma \mathrm{w}$ adalah berat volume air, e adalah angka pori, dan Gs adalah berat spesifik butiran padat tanah.

Kadar air mempunyai pengaruh yang besar terhadap tingkat kepadatan yang dapat dicapai oleh suatu tanah. Disamping kadar air, faktor-faktor lain yang juga mempengaruhi pemadatan adalah jenis tanah dan usaha pemadatan.

\subsection{Fiber (serat polypropilene)}

Polypropylene berasal dari monomer $\mathrm{C}_{3} \mathrm{H}_{6}$ merupakan hidrokarbon murni, contoh: lem parafin. Serat polypropylene dapat menahan serangan kimia (Ferryndalle, 2011). Bahan ini dibuat dengan polimerisasi, merupakan molekul yang berat dan proses produksi sampai menjadi serat gabungan untuk memberikan sifat-sifat yang berguna pada serat polypropylene ini. Sifat-sifat yang dapat diperbaiki oleh polypropylene:

a. Daktilitas : berhubungan dengan kemampuan dalam menyerap energi

b. Ketahanan terhadap beban kejut (impact resistance)

c. Kemampuan menahan tarik dan momen lentur

d. Ketahanan terhadap kelelahan

e. Ketahanan pengaruh susutan (Shrinkage)

f. Ketahanan Aus

Dari penelitian yang telah dilakukan Yohanes L. D. Adianto, Tri Basuki Joewono penelitian pendahuluan hubungan penambahan serat polymeric terhadap karakteristik beton normal serat polypropylene bisa meningkatkan kuat tekan beton. Peningkatan hasil pengujian kekuatan dalam peningkatan modulus untuk polypropylene mungkin dapat signifikan ketika kuat impact pada beton polypropylene dipertimbangkan dan mungkin lebih penting untuk mortar.

\subsection{Kuat Geser Tanah}

Kuat geser atau tepatnya ketahanan geser ini perlu diketahui untuk analisis stabilitas tanah. Menurut Braja M. Das 1985, kekuatan geser suatu massa tanah merupakan perlawanan internal tanah tersebut persatuan luas terhadap keruntuhan 
atau pergeseran sepanjang bidang geser dalam tanah yang dimaksud. Untuk menganalisis masalah stabilitas tanah seperti daya dukung, stabilitas talud (lereng), dan tekanan tanah ke samping pada turap maupun tembok penahan tanah, mula-mula kita harus mengetahui sifat-sifat ketahanan penggesernya tanah tersebut. Untuk sebagian besar masalah-masalah mekanika tanah, garis tersebut cukup didekati dengan sebuah garis lurus yang menunjukkan hubungan linear antara tegangan normal dan geser (Coulomb, 1776).

$$
\tau_{f}=c+\sigma \tan \phi
$$

Dimana $\tau_{f}$ adalah tekanan geser pada bidang runtuh, $c$ adalah kohesi, $\sigma$ adalah tekanan efektif, dan $\phi$ adalah sudut geser dalam.

Hubungan di atas disebut juga sebagai kriteria keruntuhan Mohr-Coulomb. Pada tanah jenuh air, besar tegangan normal total pada sebuah titik adalah sama dengan jumlah tegangan efektifnya ditambah dengan tegangan air pori, atau

$$
c=\sigma^{\prime}+u
$$

Tegangan efektif $\sigma^{`}$, diterima oleh bagian butiran padat dari tanah. Jadi berdasarkan prinsip mekanika tanah, persamaan dapat ditulis menjadi :

$$
\begin{aligned}
\tau_{f} & =c+(\sigma-u) \tan \phi \\
\tau_{f} & =c+\sigma^{\prime} \tan \phi
\end{aligned}
$$

\subsection{Pengujian Triaksial UU}

Uji geser triaksial adalah uji yang paling dapat diandalkan untuk menentukan parameter tegangan geser. Bila sampel tanah lempung dikonsolidasi pada tegangan sel sebesar $\sigma_{3}$ dan kemudian ditekan (geser) sampai mencapai keruntuhan tanpa mengizinkan adanya pengaliran air dari dan ke dalam benda uji, kondisi tegangan total pada saat runtuh dapat digambarkan dengan lingkaran Mohr P pada gambar 2.

Karena kekuatan geser kondisi air termampatkan dari tanah tidak tergantung pada tegangan penyekap, maka persamaan kuat geser dapat dinyatakan dalam persamaan 8 sebagai berikut :

$$
\tau_{f}=\frac{\sigma_{1}}{2}=\frac{q_{u}}{2}=C_{u}
$$

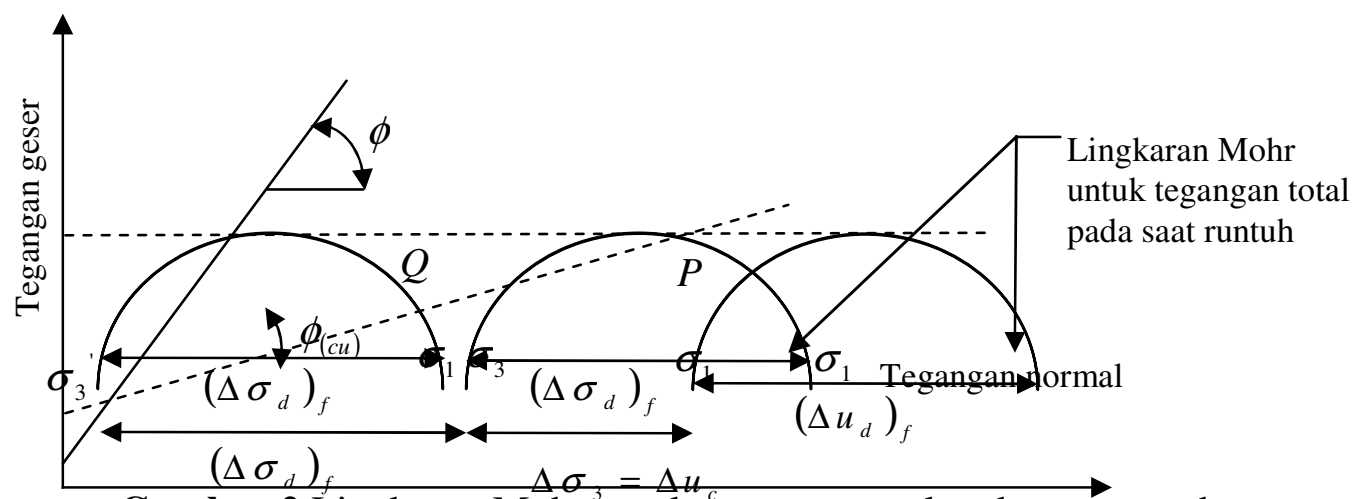

Gambar 2 Lingkaran Mohr untuk tegangan total pada saat runtuh Sumber : Braja M. Das (1985) 


\section{Metode Penelitian}

\subsection{Tahapan Pelaksanaan Penelitian}

Tahapan penelitian ini dimulai dari studi literatur yang dilanjutkan dengan persiapan pengumpulan bahan. Pada pengumpulan bahan terbagi dua bagian yaitu pengujian sifat fisis dan pengujian sifat mekanis. Tahapan yang dilakukan selanjutnya yaitu mengetahui sifat fisis tanah terlebih dahulu seperti kadar air, berat jenis, berat volume, Atterberg Limit, analisa saringan, Hydrometer, dan klasifikasi tanah. Kemudian dapat dilanjutkan dengan mengetahui sifat mekanis tanah yaitu dengan menambahkan serat polypropylene ke dalam tanah dengan dilakukan pengujian Proctor Test dan Uji Triaksial. Tanah yang digunakan adalah jenis tanah lempung yang berasal dari kawasan Gampong Mane Krueng Kecamatan Blang Mangat Kota Lhokseumawe. Fiber (serat polypropylene) yang digunakan yang dicampurkan dengan beberapa bahan kimia (bahan komposit) yang bereaksi dan mengeras dalam waktu tertentu.

\subsection{Pembuatan Benda Uji}

Jumlah benda uji yang dibuat tergantung dari cara pencampurannya, jumlah layer, penataan susunan lapisan tanah, panjang serat yang digunakan serta persentase penggunaan serat.

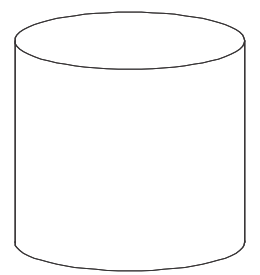

a. Tanah asli

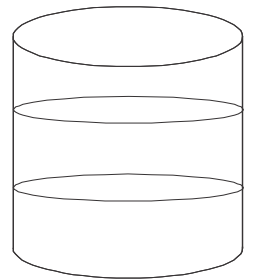

c. Lima lapis

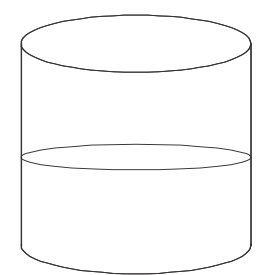

b. Tiga lapis

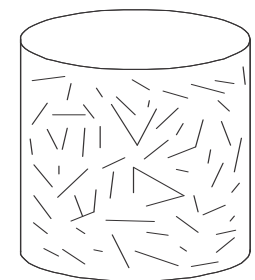

d. random (acak)

Gambar 3 Penambahan Fiber (serat polypropylene) ke dalam Tanah.

Tabel 3 Variasi Penambahan Material untuk Pengujian Pemadatan (Proctor Test) dan Pengujian Triaksial Tipe UU

\begin{tabular}{|c|l|c|}
\hline No & \multicolumn{1}{|c|}{ Jenis Pengujian } & Jumlah sampel \\
\hline 1. & Tanah asli (tanpa penambahan) & 3 Buah \\
2. & Tanah + Fiber 3\% (satu lapisan) & 3 Buah \\
3. & Tanah + Fiber 5\% (dua lapisan) & 3 Buah \\
4. & Tanah + Fiber (random) & $3 \mathrm{Buah}$ \\
\hline & Jumlah sampel & 12 Buah \\
\hline
\end{tabular}

Pada percobaan ini cara pencampuran yang akan dipakai yaitu dengan dua cara diantaranya adalah secara random (acak) dan dengan disusun menjadi 
lapisan-lapisan (layer). Jumlah layer yang akan digunakan ada dua yaitu tiga lapis dan lima lapis, tiga lapis terdiri dari dua lapis tanah dan satu lapis serat polypropylene sedangkan lima lapis terdiri dari tiga lapis tanah dan dua lapis serat polypropylene. Untuk penataan serat polypropylene diperlihatkan pada Gambar 3

\section{Hasil dan Pembahasan}

\subsection{Hasil}

Berdasarkan hasil penelitian yang dilakukan di Laboratorium Mekanika Tanah, jurusan Teknik Sipil, Universitas Malikussaleh. Tanah lempung yang berasal dari Gampong Mane Krueng, Kecamatan Blang Mangat Kota Lhokseumawe mengandung kadar air sebesar 23,497\%. Berdasarkan hasil perhitungan maka didapat berat volume tanah rata-rata $1,893 \mathrm{gram} / \mathrm{cm}^{3}$, berat jenis tanah rata-rata 2.541 , dan nilai kadar air rata-rata untuk batas plastis tanah yang di uji sebesar 40,905\%. Hasil pengujian batas cair pada 25 ketukan berdasarkan Gambar 4 adalah $65,00 \%$, maka sesuai persamaan yang di dapatkan $y=-0,381 x+75,23$ batas cair sebesar $65,705 \%$ dan untuk indek plastis $24,800 \%$, Hasil dari perhitungan untuk indek grup mendapatkan nilai sebesar 21,

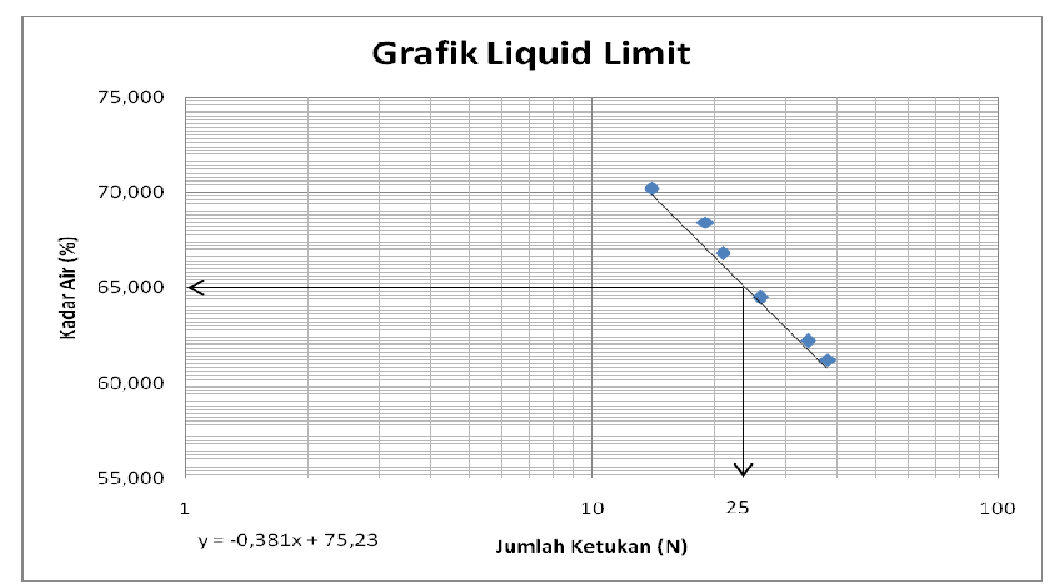

Gambar 4 Grafik Liquid Limit

Hasil pengujian analisa saringan yang lolos saringan no. 200 sebesar $72,72 \%$ dan untuk analisa hydrometer D10 $=0,000, \mathrm{D} 30=0,007, \mathrm{D} 60=0,035$, diperlihatkan pada Gambar 5.

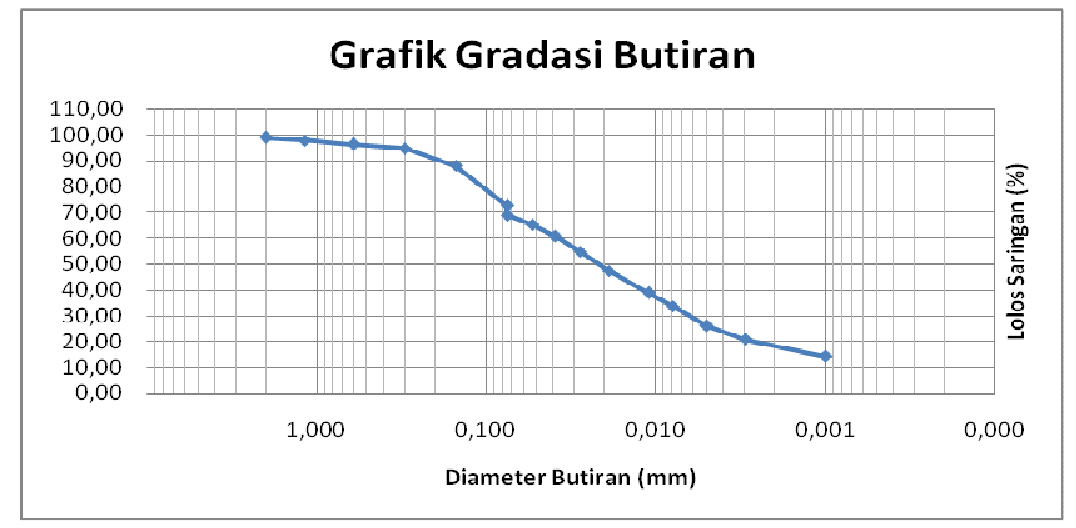

Gambar 5 Grafik Gradasi Butiran 
Berdasarkan sistem klasifikasi AASTHO, maka tanah dari Desa Mane Krueng Kecamatan Blang Mangat Kota Lhokseumawe dapat klasifikasikan kedalam kelompok (tanah berlempung, A-7-5.

\subsubsection{Pengujian pemadatan (proctor test)}

Hasil pengujian pemadatan (proctor test), untuk tanah asli (sampel I) diperoleh nilai kadar air optimum $\left(\omega_{\text {optimum }}\right)=25,5 \%$, dan kepadatan kering $\left(\gamma_{\text {dmax }}\right)$ $=1,423 \mathrm{gram} / \mathrm{cm}^{3}$.

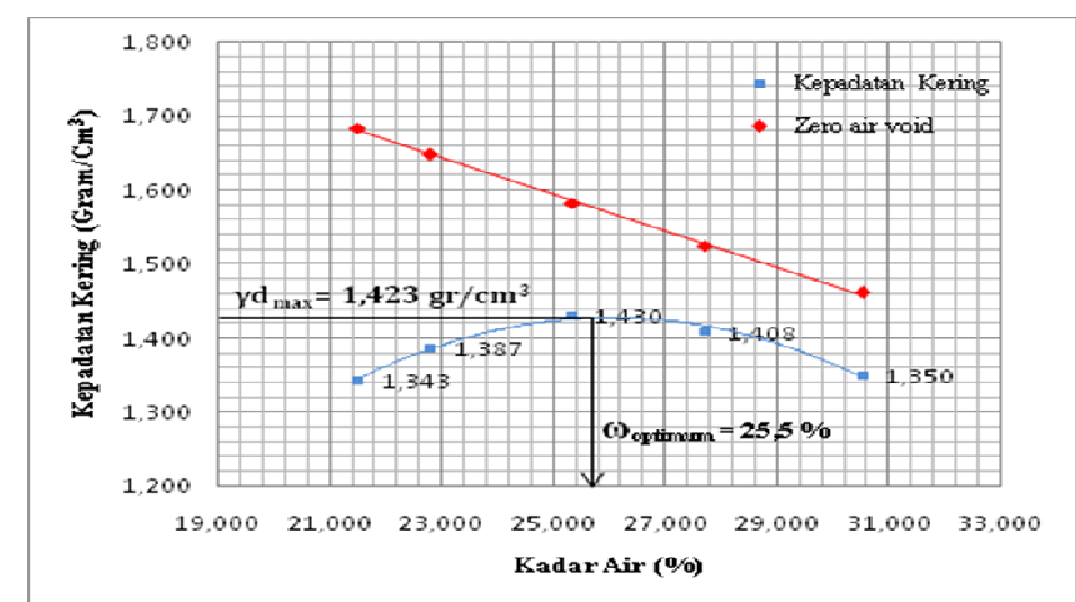

\section{Gambar 6 Grafik Pemadatan Tanah Asli Untuk 3\% (1 lapisan) penambahan serat polypropylene (sampel I)}

diperoleh nilai kadar air optimum $\left(\omega_{\text {optimum }}\right)=23,0 \%$, dan kepadatan kering $\left(\gamma_{\mathrm{dmax}}\right)=1,458 \mathrm{gram} / \mathrm{cm}^{3}$.

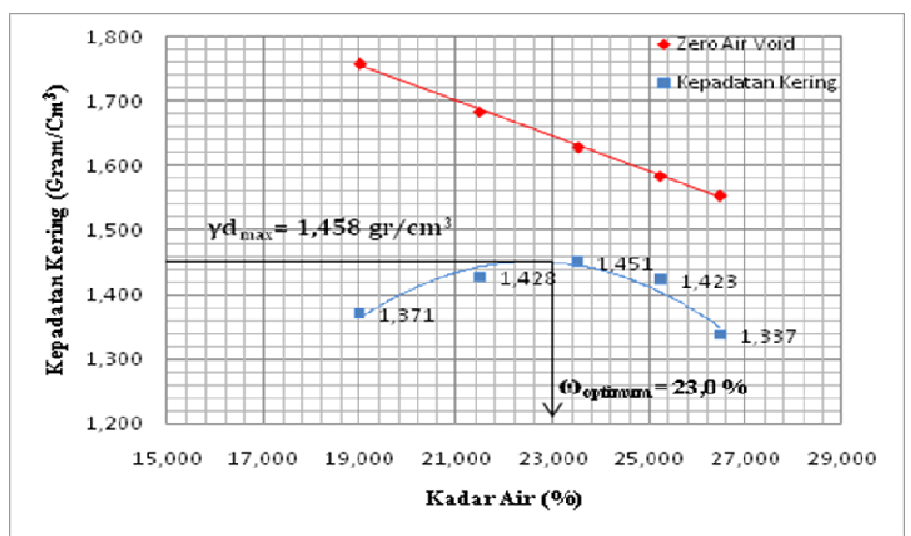

\section{Gambar 7 Grafik Pemadatan Tanah Asli + 3\% polypropylene (Sampel I)}

Untuk 5\% (2 lapisan) penambahan serat polypropylene (sampel I) diperoleh nilai kadar air optimum $\left(\omega_{\text {optimum }}\right)=23,3 \%$, dan kepadatan kering $\left(\gamma_{\text {dmax }}\right)=1,460$ gram $/ \mathrm{cm}^{3}$, dapat dilihat pada Gambar 8 . Untuk $7 \%$ (tidak beraturan) penambahan serat polypropylene (sampel I) diperoleh nilai kadar air optimum $\left(\omega_{\text {optimum }}\right)=$ $23,1 \%$, dan kepadatan kering $\left(\gamma_{\mathrm{dmax}}\right)=1,450 \mathrm{gram} / \mathrm{cm}^{3}$, dapat dilihat pada Gambar 9. 


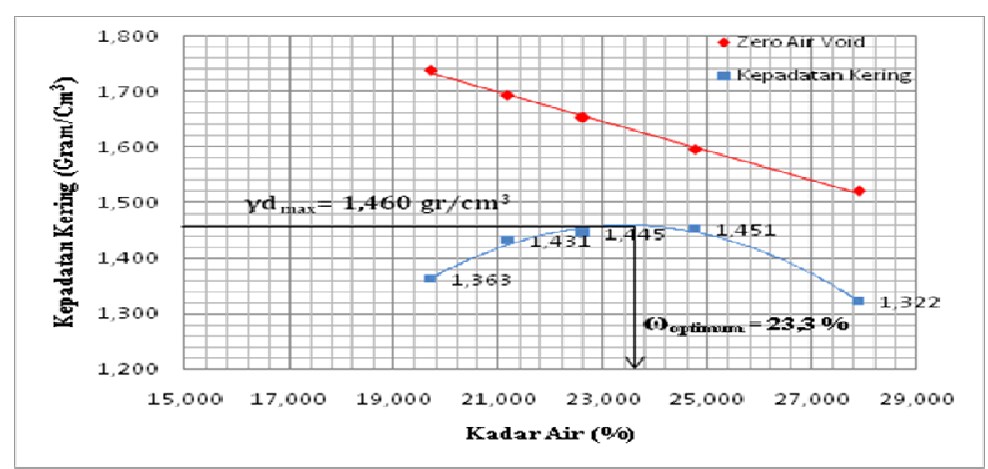

Gambar 8 Grafik Pemadatan Tanah Asli + 5\% polypropylene (Sampel I)

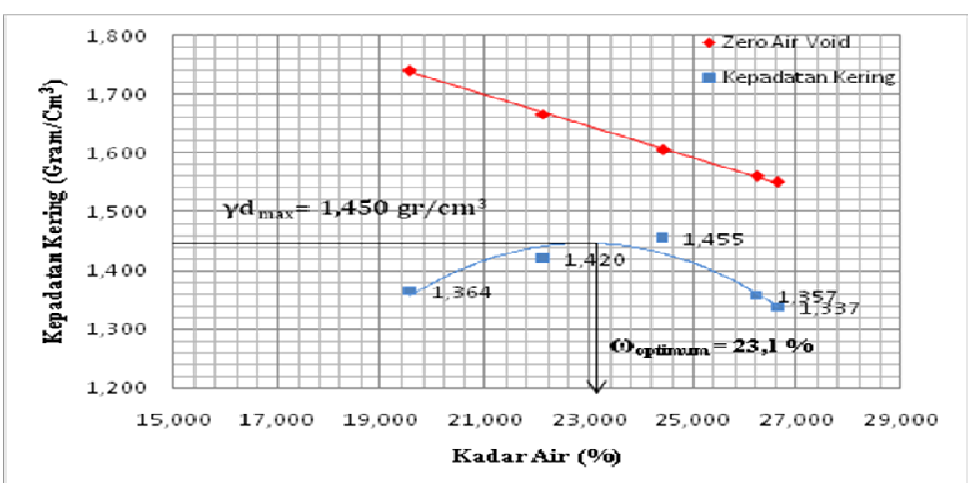

\section{Gambar 9 Grafik Pemadatan Tanah Asli + 7\% polypropylene (Sampel I)}

\subsubsection{Pengujian Triaksial Laboratorium}

Pada pengujian Triaksial penambahan serat polypropylene dengan variasi seperti $0 \%$ tanah asli, 3\% (1 lapisan), 5\% (2 lapisan), 7\% acak (tidak beraturan). Kadar air yang dipakai adalah kadar air optimum $\left(W_{\text {opt }}\right)$ yang didapat dari hasil pengujian proktor test. Dengan benda uji 3 sampel, sampel I diberikan $\sigma 3=0,5 \mathrm{~kg} / \mathrm{cm}^{2}$, sampel II $\sigma 3=1 \mathrm{~kg} / \mathrm{cm}^{2}$, sampel III $\sigma 3=1,5 \mathrm{~kg} / \mathrm{cm}^{2}$. Jadi benda uji keseluruhannya dalam pengujian Triaksial ada 12 sampel benda uji.

Tabel 4.2 Hasil Keseluruhan Pengujian Triaksial

\begin{tabular}{|c|c|c|c|c|c|}
\hline No & $\begin{array}{l}\text { Penambahan serat } \\
\text { polypropylene (\%) }\end{array}$ & $\begin{array}{c}\sigma 3 \\
\mathrm{~kg} / \mathrm{cm}^{2}\end{array}$ & $\begin{array}{c}\sigma 1 \\
\mathrm{~kg} / \mathrm{cm}^{2}\end{array}$ & $\square\left({ }^{\circ}\right)$ & $\mathrm{c}\left(\mathrm{kg} / \mathrm{cm}^{2}\right)$ \\
\hline \multirow{3}{*}{1} & \multirow{3}{*}{ Tanah asli } & 0,5 & 30,31 & \multirow{3}{*}{41} & \multirow{3}{*}{6,402} \\
\hline & & 1 & 33,33 & & \\
\hline & & 1,5 & 35,16 & & \\
\hline \multirow{3}{*}{2} & \multirow{3}{*}{3 (1 lapisan) } & 0,5 & 20,34 & \multirow{3}{*}{18} & \multirow{3}{*}{6,963} \\
\hline & & 1 & 21,40 & & \\
\hline & & 1,5 & 22,20 & & \\
\hline \multirow{3}{*}{3} & \multirow{3}{*}{5 (2 lapisan) } & 0,5 & 25,16 & \multirow{3}{*}{26} & \multirow{3}{*}{7,370} \\
\hline & & 1 & 26,73 & & \\
\hline & & 1,5 & 27,69 & & \\
\hline \multirow{3}{*}{4} & \multirow{3}{*}{7 (acak) } & 0,5 & 22,69 & \multirow{3}{*}{13} & \multirow{3}{*}{8,609} \\
\hline & & 1 & 23,64 & & \\
\hline & & 1,5 & 24,24 & & \\
\hline
\end{tabular}

Uji Triaksial digunakan yaitu tipe Unconsolidated-Undrained (UU). Pada uji air-termapatkan-tak tekonsolidasi, tidak diizinkan air keluar dari benda ujinya. 
Jadi, selama pengujian katup drainasi ditutup selama memberi tekanan sel $\square 3$. Benda uji di uji sampai runtuh dengan memberikan tekanan deviator $\square \square_{\mathrm{d}}$. Hasil dan nilai-nilai dari Triaksial tersebut digambarkan dalam bentuk gafik dan divisualisasikan dengan lingkaran Mohr, hasil keseluruhan nilai Triaksial diperlihatkan pada Tabel 4.

\subsection{Pembahasan}

Dari hasil penelitian sampel tanah merupakan tanah berlempung (menurut AASHTHO), untuk serat polypropylene yang digunakan adalah mudah didapatkan di pasaran. Sesuai dengan permasalahan yang ada pada tanah lempung yaitu bersifat sangat kohesif, kenaikan air tinggi diadakan penelitian dengan serat sebagai bahan stabilisasinya. Hasil yang didapat dari pengujian triaksial yaitu untuk tanah asli $\mathrm{c}=6,402 \mathrm{~kg} / \mathrm{cm}^{2}$ dan $\square=41^{\circ}$, tanah ditambah $3 \%$ (1 lapisan) polypropylene $\mathrm{c}=6,963 \mathrm{~kg} / \mathrm{cm}^{2}$ dan $\square=18^{\circ}$, tanah ditambah $5 \%$ (2 lapisan) polypropylene $\mathrm{c}=7,370 \mathrm{~kg} / \mathrm{cm}^{2}$ dan $\square=26^{\circ}$, tanah ditambah $7 \%$ (secara acak) polypropylene $\mathrm{c}=8,609 \mathrm{~kg} / \mathrm{cm}^{2}$ dan $\square=13^{\circ}$. Semakin ada penambahan serat polypropylene maka semakin besar pengaruh nilai parameter kuat geser tanah di karenakan daya tarik permukaan partikel antara tanah dan fiber semakin besar serta akibat karakteristik fiber tersebut. Pengaruh hasil sudut geser yang bervariasi dikarenakan penambahan serat yang ditidak seragam atau tidak sama.

\section{Kesimpulan dan Saran}

\subsection{Kesimpulan}

Berdasarkan hasil penelitian dapat diambil kesimpulan-kesimpulan sebagai berikut:

1. Sampel tanah berdasarkan sistem AASHTO, termasuk kedalam kelompok A-75 (21) dengan klasifikasi tanah berlempung.

2. Pada pengujian laboratorium, tanah memiliki kadar air $23,497 \%$, berat jenis (Gs) 2,641 , berat volume $1,893 \mathrm{gr} / \mathrm{cm} 3$, batas cair (LL) $65,705 \%$, batas plastis (PL) 40,905, dan indeks plastis (IP) 24,800.

3. Hasil dari pengujian Proctor Standar didapat berat volume kering $(\gamma d)$ sebesar $1,423 \mathrm{gr} / \mathrm{cm} 3$ dengan kadar air optimum $\left(\mathrm{W}_{\text {opt }}\right) 25,5 \%$

4. Dari pengujian triaksial untuk tanah asli $\mathrm{c}=6,402 \mathrm{~kg} / \mathrm{cm}^{2}, 3 \%$ polypropylene $\mathrm{c}$ $=6,963 \mathrm{~kg} / \mathrm{cm}^{2}, 5 \%$ polypropylene $\mathrm{c}=7,370 \mathrm{~kg} / \mathrm{cm}^{2}, 7 \%$ polypropylene $\mathrm{c}=$ $8,609 \mathrm{~kg} / \mathrm{cm}^{2}$. Semakin ada penambahan serat polypropylene maka semakin besar nilai kuat geser tanah dikarenakan daya tarik permukaan partikel antara tanah dan fiber semakin besar serta akibat karakteristik fiber tersebut.

5. Dari hasil pengujian sudut geser untuk tanah asli $\square=41^{\circ}$, untuk $3 \%$ (1 lapisan) serat $\square=18^{\circ}$, untuk $5 \%$ (2 lapisan)serat $\square=26^{\circ}$, untuk $7 \%$ (acak) serat $\square=$ $13^{\circ}$, pengaruh hasil sudut geser yang bervariasi dikarenakan penambahan serat yang ditidak seragam atau tidak sama.

\subsection{Saran}

Saran yang dapat diberikan sebagai bentuk rekomendasi dari hasil penelitian ini sebagai berikut:

1. Agar mendapatkan hasil yang optimal, maka sebaiknya alat-alat yang akan digunakan dicek atau dicoba terlebih dahulu apakah alat tersebut dapat bekerja secara baik dan akurat. 
2. Bagi para peneliti yang ingin melakukan penelitian lanjutan dapat memakai jenis tanah yang sama atau berbeda dengan persentase dan bahan pencampur yang berbeda. Dan memakai tipe Triaksial yang berbeda seperti CU (Consolidasi-Undrianed) dan CD (Consolidasi-Drianed).

\section{Daftar Kepustakaan}

1. ASTM D 2850-87 (Unconsolidated-Undrained)

2. Bowles, J.E., 1993, Sifat-Sifat Dan Geoteknik Tanah, Terjemahan Hainim,J.K., erlangga, Jakarta

3. B.Peck Ralph dan Karl Terzaghi, 1993, Mekanika Tanah Dalam Praktek Rekayasa Edisi Kedua Jilid 1, Erlangga, Jakarta.

4. Das .Braja M ., 1995, Mekanika Tanah (Prinsip-Prinsip Rekayasa Geoteknis) Jilid I, Erlangga, Jakarta

5. Das, Braja M, 1985, Mekanika Tanah (Prinsip-Prinsip Rekayasa Geoteknis) Jilid II, Erlangga, Jakarta.

6. Ferryndalle, 2011, Sifat Serat Polypropylene, http://www.ferryndalle.com/ 2011/11/sifat-serat-polypropylene.html, di unduh pada tanggal 18 Nopember 2012.

7. Hardiyatmo, Hary Cristiady, 1992, Mekanika Tanah 1, Gramedia Pustaka Utama, Jakarta.

8. Soedarmo G.Djatmiko dan S.J Edy Purnomo, 1997, Mekanika Tanah 1, Kanisius, Yogyakarta.

9. Wesley, 1977, mekanika tanah, cetakan keenam . bandung.

10. Wahyu Kartini, Penggunaan serat polypropylene untuk meningkatkan kuat tarik belah beton http://eprints.upnjatim.ac.id/1306/1/TS-YUYUN_41.pdf, di unduh tanggal 26 Nopember 2012

11. Yohanes L. D. Adianto, Tri Basuki Joewono, 2006, Penelitian pendahuluan hubungan penambahan Serat polymeric terhadap karakteristik beton normal , http://puslit.petra.ac.id/files/published/journals/CIV/CIV060801/ CIV06080106.pdf di unduh tanggal 2 Januari 2013. 